\title{
Inherited epidermolysis bullosa
}

INSERM

\section{Source}

INSERM. (1999). Orphanet: an online rare disease and orphan drug data base. Inherited epidermolysis bullosa. ORPHA:79361

Inherited epidermolysis bullosa (EB) encompasses a number of disorders characterized by recurrent blister formation as the result of structural fragility within the skin and selected other tissues. 